\title{
EFFECTS OF SINGLE AND CONTINUOUS ADMINISTRATION OF AMYLOID $\beta$-PEPTIDE (25-35) ON ADENYLYL CYCLASE ACTIVITY AND THE SOMATOSTATINERGIC SYSTEM IN THE RAT FRONTAL AND PARIETAL CORTEX
}

\section{A. HERVÁS-AGUILAR, L. PUEBLA-JIMÉNEZ, E. BURGOS-RAMOS, D. AGUADO-LLERA AND E. ARILLA-FERREIRO*}

Grupo de Neurobioquímica, Departamento de Bioquímica y Biología Molecular, Facultad de Medicina, Ctra. Madrid-Barcelona km 33,6, Universidad de Alcalá, E-28871, Alcalá de Henares, Madrid, Spain

\begin{abstract}
It is unknown whether the amyloid $\beta$-peptide $(A \beta)$, a principal component found in extracellular neuritic plaques in the brain of patients with Alzheimer's disease (AD), is capable of altering adenylyl cyclase (AC) activity and the somatostatin (SRIF) receptor-effector system in the cerebral cortex of the patients. Therefore, the objective of this study was to investigate the effect of the $\beta$ fragment, $\beta$ (25-35), on $A C$ activity and the somatostatinergic system in the rat frontoparietal cortex. A single dose of $\beta(25-35)(10 \mu \mathrm{g})$ injected intracerebroventricularly significantly decreased the density of SRIF receptors $(27.4 \%)$ and increased their affinity $(32.2 \%)$ in the frontoparietal cortex. The inhibitory effect of SRIF on basal and forskolin (FK)-stimulated AC activity was significantly lower in the $\beta$ (25-35)-treated rats when compared with controls. $\beta$ (25-35) did not modify Gi $\alpha 1$, Gi $\alpha 2$ nor Gi 33 levels in membranes from the frontoparietal cortex. Continuous infusion of the peptide induced a decrease in the SRIF receptor density in this brain area to a similar extent as that observed 14 days after the single administration of the peptide. Likewise, this treatment decreased the SRIF receptor density in the frontal cortex $(15.3 \%)$ and parietal cortex $(27.2 \%)$. This effect was accompanied by a decrease in the SRIF-mediated inhibition of FK-stimulated AC activity (from $41.6 \%$ to $25.6 \%$ ) in the frontal cortex as well by a decrease in basal AC activity (from $36.9 \%$ to $31.6 \%$ ) and FK-stimulated AC activity (from $35.6 \%$ to $27.1 \%$ ) in the parietal cortex. Continuous infusion of

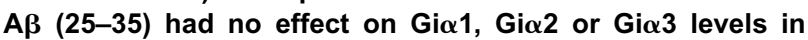
membranes from frontal and parietal cortex. However, this treatment caused a decrease in SRIF-like immunoreactivity content in the parietal $(38.9 \%)$ and frontal $(20.4 \%)$ cortex. These results suggest that $A \beta$ might be involved in the alterations of somatostatinergic system reported in AD. (๑) 2005 Published by Elsevier Ltd on behalf of IBRO.
\end{abstract}

Key words: brain, Alzheimer's disease, somatostatin receptors, cerebral cortex.

${ }^{*}$ Corresponding author. Tel: +34-91-885-4509; fax: +34-91-885-4585. E-mail address: lilian.puebla@uah.es (E. Arilla-Ferreiro).

Abbreviations: $A \beta$, amyloid $\beta$-peptide; $A \beta(25-35)$, amyloid $\beta$-peptide fragment (25-35); $A C$, adenylyl cyclase; $A D$, Alzheimer's disease; BSA, bovine serum albumin; cAMP, cyclic AMP; CRE, cyclic AMP response element; CREB, cyclic AMP-response element-binding protein; FK, forskolin; IBMX, 3-isobutyl-1-methylxanthine; PMSF, phenylmethylsulfonyl fluoride; SRIF, somatostatin; SRIF-LI, somatostatin-like immunoreactivity.

0306-4522/05 $\$ 30.00+0.00$ @ 2005 Published by Elsevier Ltd on behalf of IBRO doi:10.1016/j.neuroscience.2005.02.017
Alzheimer's disease (AD) is the most common form of senile dementia, accounting for more than $50 \%$ of the cases reported. The prevalence increases logarithmically with age (Katzman and Saitoh, 1991). The main pathological features of $A D$ are extracellular deposits of amyloid $\beta$-peptide $(A \beta)$, intraneuronal cytoskeletal abnormalities and neuronal degeneration (Armstrong et al., 1991). The neurotoxicity of $A \beta$ was first demonstrated by Yankner et al. (1990). In addition to a direct neurotoxic effect, $A \beta$ activates microglia to produce neurotoxins, such as proteolytic enzymes, cytokines, free radicals and nitric oxide (Meda et al., 1995). Neurochemical studies on postmortem brains from $A D$ patients have demonstrated changes in several neurotransmitter systems (Cowburn et al., 1996). The most consistent finding is a deficit in choline acetyltransferase activity in the cerebral cortex (Koshimura et al., 1986). Recent reports suggest that neurotransmitter receptors are affected in $A D$ patients, more profoundly in younger patients (Greenamyre et al., 1985; Pavia et al., 2000). Noradrenergic, serotonergic and possibly dopaminergic neurons are also affected, although to a lesser extent (Reinikainen et al., 1990). The GABAergic interneurons have also been shown to be involved in $A D$ (Cagnin et al., 2001). Among the neuropeptides, the most consistently reported deficit in $A D$ is the reduction in the cortical somatostatin (SRIF) concentration (Davies et al., 1980). Regarding the SRIF receptors, several authors (Beal et al., 1985; Bergström et al., 1991; Krantic et al., 1992) have reported a marked loss in the SRIF receptor density in various cortical areas of the $A D$ brain. Cowburn et al. (1991) found a reduced SRIF-mediated inhibition of adenylyl cyclase $(A C)$ activity in the superior temporal cortex of $A D$ brains as compared with controls.

SRIF is widely distributed in the CNS and peripheral tissues and is considered as a hormone, neurohormone and neuromodulator (Epelbaum, 1986). In addition to its multiple neuroendocrine effects, SRIF has been also suggested to modulate cognitive processes (Vécsei et al., 1984; Cacabelos et al., 1988; Dournaud et al., 1996). The somatostatinergic innervation of the cerebral cortex is of intrinsic origen (Epelbaum, 1986). In fact, SRIF mRNAs and immunoreactive SRIF are present in nonpyramidal neurons mainly localized in layers II-III and V-VI. These neurons display vertical axonal arborization that often terminates in layer I (Garrett et al., 1994). Autoradiographic studies conducted in the adult neocortex have demonstrated that SRIF receptors are located primarily in layers 
V-VI and to a lesser extent in layers I-IV. Several studies have demonstrated that not only neurons but also astrocytes and microglial cells express SRIF receptors (Feindt et al., 1995, 1998). The frontoparietal cortex contains high levels of SRIF receptors (Srikant et al., 1981; Epelbaum et al., 1982). Five SRIF receptors have been cloned to date (Bell and Reisine, 1993), which are all coupled to AC via the guanine nucleotide-binding inhibitory protein Gi (Sakamoto et al., 1988; Schettini et al., 1989).

To date, it is unknown whether $A \beta$ is capable of altering $A C$ activity and the SRIF receptor-effector system in the cerebral cortex. Numerous laboratories have used the smaller 11 amino acid fragment of the full-length peptide, amyloid $\beta$-peptide fragment (25-35) (A $\beta$ (25-35)), as a convenient alternative in $A D$ research since the smaller peptide mimics several of the toxicological and oxidative stress properties of the native full-length peptide. A $\beta$ (2535 ) is more rapidly toxic and causes more oxidative damage than the parent peptide $A \beta$ (1-42) (Varadarajan et al., 2001).

The aim of this study, therefore, was to investigate the effect of $A \beta(25-35)$ on $A C$ and the somatostatinergic system in the rat frontoparietal cortex. Consequently, we examined the binding of ${ }^{125} \mathrm{I}-\mathrm{Tyr}^{11}$-SRIF to SRIF receptors, basal and forskolin (FK)-stimulated $A C$ activity and SRIF-mediated inhibition of AC activity in membranes from the rat frontoparietal cortex as well as from the frontal or parietal cortex alone. somatostatin-like immunoreactivity (SRIF-LI) levels and $\mathrm{Gi}$ protein levels $\left(\mathrm{Gi} \alpha_{1}, \mathrm{Gi} \alpha_{2}\right.$ and $\left.\mathrm{Gi} \alpha_{3}\right)$ in these brain areas were also determined after single or continuous administration of $A \beta(25-35)$.

\section{EXPERIMENTAL PROCEDURES}

Synthetic Tyr $^{11}$-SRIF and SRIF-14 were purchased from Universal Biologicals Ltd (Cambridge, UK); carrier-free Na ${ }^{125}$ I (IMS 100 $\mathrm{mCi} / \mathrm{ml}$ ) was purchased from the Radiochemical Center (PerkinEImer, Boston, Massachusetts, USA); bacitracin, bovine serum albumin (BSA), forskolin (FK), $A \beta$ (25-35), $A \beta$ (35-25), phenylmethylsulfonyl fluoride (PMSF), guanosine triphosphate, and 3-isobutyl-1-methylxanthine (IBMX) were purchased from Sigma (Madrid, Spain). Specific antisera against the $\alpha i 1$ (MAB 3075 ) and $\alpha$ i2 (MAB 3077) G protein subunits were obtained from Chemicon International (Temecula, California, USA) whereas antiserum against the $\alpha i 3$ (sc-262) G protein subunit was obtained from Santa Cruz Biotechnology Inc. (Santa Cruz, California, USA). Nitrocellulose membranes as well as the chemiluminescence Western blotting detection system were purchased from Amersham (Buckinghamshire, UK). The rabbit antibody used in the radioimmunoassay technique was raised in rabbits against SRIF-14 conjugated to BSA and is specific for SRIF, but since SRIF-14 constitutes the C-terminal portions of both SRIF-25 and SRIF-28, the antiserum does not distinguish between these three forms. The binding of SRIF-14 to this antibody does not depend on an intact disulfide bond in the molecule as breaking of the disulfide bond by reaction with $0.1 \%$ mercaptoethanol (boiling water bath, $5 \mathrm{~min}$ ) did not change the immunoreactivity of the peptide.

Cross-reactivity with other peptides was less than $0.5 \%$. Cross-reaction with several SRIF analogs demonstrated that neither the $\mathrm{N}$-terminal glycine nor the $\mathrm{C}$-terminal cysteine residue is required for antibody binding, suggesting that the antigen site is directed toward the central part of the molecule containing the tryptophan residue.

\section{Experimental animals}

The animal experiments performed in the present study conform to the guidelines set by the Animal Care Committee of Alcalá University and were performed in accordance with the European Communities Council Directive for the care of laboratory animals. Great care was taken to avoid or minimize discomfort to the animals. The animals used in this study were 50 male Wistar rats weighing between 200 and $250 \mathrm{~g}$. Rats were maintained on a 12-h light/dark cycle $(07: 00-19: 00 \mathrm{~h})$ and allowed free access to food and water. The $A \beta(25-35)$ peptide as well as the scrambled peptide $A \beta$ (35-25) were dissolved in distilled water, which favors aggregation (Pike et al., 1995), and administered i.c.v. to the rats in a single dose (10 $\mu \mathrm{g}$; Giovannelli et al., 1995) or via an osmotic minipump (Alzet) connected to a cannula. On the day of surgery, the cannula attached to the osmotic minipump was implanted in the right cerebral ventricle of the rat as previously described (Nitta et al.1994) and $A \beta(25-35)$ was continuously infused at doses of $300 \mathrm{pmol} /$ day for 14 days (Nitta et al., 1994; Nag et al., 1999). Control animals received vehicle alone. The rats were killed by decapitation 7 or 14 days after the single injection or 14 days after the minipump implantation. All solutions were freshly prepared prior to administration. In all experimental groups, the brains were rapidly removed and the frontoparietal cortex, frontal cortex and parietal cortex were dissected over ice according to the method of Glowinski and Iversen (1966).

\section{Tissue extraction and SRIF radioimmunoassay}

For SRIF-LI measurements, the frontoparietal cortex was rapidly homogenized in $1 \mathrm{ml}$ of $2 \mathrm{M}$ acetic acid using a Brinkman polytron (setting $5,30 \mathrm{~s}$ ). The extracts were boiled for $5 \mathrm{~min}$ in a water bath, chilled in ice, and aliquots $(100 \mu \mathrm{l})$ were removed for protein determination (Patel and Reichlin, 1978). The homogenates were subsequently centrifuged at $15,000 \times \mathrm{g}$ for $15 \mathrm{~min}$ at $4{ }^{\circ} \mathrm{C}$ and the supernatant was neutralized with $2 \mathrm{M} \mathrm{NaOH}$. The extracts were then stored at $-70{ }^{\circ} \mathrm{C}$ until assay. The tissue concentration of SRIF-LI was analyzed in the extracts by a competitive radioimmunoassay, as previously reported (Patel and Reichlin 1978), with a sensitivity limit of $10 \mathrm{pg} / \mathrm{ml}$. All samples from a given brain region were assayed on the same radioimmunoassay run. Incubation tubes prepared in duplicate contained $100 \mu$ l samples of unknown or standard solutions of $0-500 \mathrm{pg}$ cyclic SRIF tetradecapeptide diluted in phosphate buffer $(0.1 \mathrm{M}, \mathrm{pH} 7.5$ containing $0.2 \% \mathrm{BSA}$, $0.1 \%$ sodium azide), $200 \mu \mathrm{l}$ of appropriately diluted anti-SRIF serum, $100 \mu$ l of freshly prepared ${ }^{125}$ I-Tyr ${ }^{11}$-SRIF diluted in buffer to give $6000 \mathrm{cpm} /$ assay tube (equivalent to $5-10 \mathrm{pg}$ ), and enough buffer to give a final volume of $0.8 \mathrm{ml}$. All reagents, as well as the assay tubes, were kept chilled in ice before their incubation for $24 \mathrm{~h}$ at $4{ }^{\circ} \mathrm{C}$. Separation of bound and free hormone was accomplished by the addition of $1 \mathrm{ml}$ of dextran-coated charcoal (dextran T-70: $0.2 \% \mathrm{w} / \mathrm{v}$; Pharmacia, Uppsala, Sweden; charcoal Norit A: $2 \%$ w/v; Serva; Feinbiochemica, Heidelberg, Germany). Serial dilution curves for the samples were parallel to the standard curve.

\section{Binding assay}

$\mathrm{Tyr}^{11}$-SRIF was radioiodinated by the chloramine-T method (Greenwood et al., 1963). The tracer was purified in a Sephadex G-25 fine column $(1 \times 100 \mathrm{~cm})$ equilibrated with $0.1 \mathrm{M}$ acetic acid containing BSA $0.1 \%(\mathrm{~W} / \mathrm{V})$. The specific activity of the purified labeled peptide was about $600 \mathrm{Ci} / \mathrm{mmol}$.

Membranes from the rat frontoparietal cortex, frontal cortex and parietal cortex were prepared as previously described by Reubi et al. (1981). Membrane protein was determined by the method of Lowry et al. (1951) using BSA as a standard. Specific SRIF binding was measured according to the modified method of Czernik and Petrack (1983). Briefly, brain membranes $(0.15 \mathrm{mg}$ protein $/ \mathrm{ml}$ ) were incubated in $250 \mu \mathrm{l}$ of a medium containing 
$50 \mathrm{mM}$ Tris-HCL buffer ( $\mathrm{pH} 7.5$ ), $5 \mathrm{mM} \mathrm{MgCl} 2,0.2 \%$ (w/v) BSA and $0.1 \mathrm{mg} / \mathrm{ml}$ bacitracin with $160 \mathrm{pM}^{125} \mathrm{I}_{\text {-Tyr }}{ }^{11}$-SRIF either in the absence or presence of $0.01-10 \mathrm{nM}$ unlabeled SRIF. After incubation for $60 \mathrm{~min}$ at $30^{\circ} \mathrm{C}$, the free radioligand was separated from the bound radioligand by centrifugation at $11,000 \times g$ for $2 \mathrm{~min}$ and the resultant pellet was counted in a Kontron gamma counter. Nonspecific binding was obtained from the amount of radioactivity bound in the presence of $10^{-7} \mathrm{M}$ unlabeled SRIF. This non-specific component was subtracted from the total bound radioactivity in order to obtain the corresponding specific binding.

\section{Evaluation of radiolabeled peptide degradation}

To determine the extent of tracer degradation during incubation, we measured the ability of pre-incubated peptide to bind to fresh membranes as previously described (Aguilera et al., 1982). Briefly, ${ }^{125}$ I-Tyr ${ }^{11}$-SRIF (250 pM) was incubated with membranes from the rat frontoparietal cortex, frontal cortex or parietal cortex $(0.15 \mathrm{mg}$ protein $/ \mathrm{ml})$ for $60 \mathrm{~min}$ at $30^{\circ} \mathrm{C}$. After this pre-incubation, aliquots of the medium were added to fresh membranes and incubated for an additional $60 \mathrm{~min}$ at $30^{\circ} \mathrm{C}$. The fraction of added radiolabeled peptide which was specifically bound during the second incubation was measured and expressed as a percentage of the binding that had been obtained in control experiments performed in the absence of membranes during the pre-incubation period.

\section{AC assay}

AC activity was measured as previously reported (Houslay et al., 1976) with minor modifications. Briefly, rat membranes from the frontoparietal, frontal or parietal cortex $(0.06 \mathrm{mg} / \mathrm{ml})$ were incubated with $1.5 \mathrm{mM}$ ATP, $5 \mathrm{mM} \mathrm{MgSO}_{4}, 10 \mu \mathrm{M}$ GTP, an ATPregenerating system $(7.5 \mathrm{mg} / \mathrm{ml}$ creatin phosphate and $1 \mathrm{mg} / \mathrm{ml}$ of creatin kinase), $1 \mathrm{mM}$ IBMX, $0.1 \mathrm{mM}$ PMSF, $1 \mathrm{mg} / \mathrm{ml}$ bacitracin, 1 mM EDTA, and test substances $\left(10^{-4} \mathrm{M}\right.$ SRIF or $\left.10^{-5} \mathrm{M} \mathrm{FK}\right)$ in $0.1 \mathrm{ml}$ of $0.025 \mathrm{M}$ triethanolamine/ $\mathrm{HCl}$ buffer $(\mathrm{pH} 7.4)$. After a 15 -min incubation at $30{ }^{\circ} \mathrm{C}$, the reaction was stopped by heating the mixture for $3 \mathrm{~min}$. After letting the tubes cool, $0.2 \mathrm{ml}$ of an alumina slurry $(0.75 \mathrm{~g} / \mathrm{ml}$ in triethanolamine/ $\mathrm{HCl}$ buffer, $\mathrm{pH} 7.4)$ were added and the suspension was centrifuged. The supernatant was taken for assay of cyclic AMP (cAMP) by the method of Gilman (1970). The SRIF concentration used was that necessary to achieve inhibition of rat (Schettini et al., 1989) and human (Bergström et al., 1991; Garlind et al., 1992) brain AC. FK was used at a concentration that could effectively stimulate the catalytic subunit of the enzyme (Seamon and Daly, 1986).

\section{Immunodetection of the $\alpha \mathbf{i}$ subunits of $\mathbf{G}$ proteins}

Membranes from the parietal, frontal or frontoparietal cortex were solubilized in SDS-sample buffer. The proteins were then run on a $12 \%$ SDS-polyacrylamide gel as described previously (Laemmli, 1970). The transfer of proteins to nitrocellulose membranes and the immunodetection of the $\alpha i 1, \alpha i 2$ and $\alpha i 3$ subunits of the $G$ proteins using the specific mouse anti-Gi monoclonal antibodies MAB3075, MAB3077 and sc-262, respectively, were carried out as described elsewhere (Mumby et al., 1986). Briefly, after protein transfer, the nitrocellulose membranes were pre-incubated with blotting buffer (50 mM Tris- $\mathrm{HCl} \mathrm{pH} \mathrm{7.5,} 150 \mathrm{mM} \mathrm{NaCl}, 0.05 \%$ (v/v) Tween-20 and $3 \%(\mathrm{w} / \mathrm{v})$ non-fat dry milk). Antisera were diluted in buffer (dilution 1:1000) and were then added to the nitrocellulose membranes. Incubation was carried out overnight at $4{ }^{\circ} \mathrm{C}$. Subsequently, excess antibody was removed and three 15-min washes with blotting buffer were carried out. After washing, the bound immunoreactive proteins were incubated with horseradishperoxidase-conjugated goat antibody to mouse $\operatorname{lgG}$ for $1 \mathrm{~h}$ at $4{ }^{\circ} \mathrm{C}$. After eliminating unbound antibody, three 5-min washes with HEPES $20 \mathrm{mM} \mathrm{pH} 7.5$ were carried out and proteins were de- tected by chemiluminescence using an ECL Western blotting analysis system (Amersham Pharmacia Biotech) according to the manufacturer's instructions. The optical density of the bands obtained was analyzed using the Scion Image program (Scion Corporation). X-ray films (Hyperfilm ECL) were exposed for $30 \mathrm{~s}-1 \mathrm{~min}$.

\section{Data analysis}

The computer program LIGAND (Munson and Rodbard, 1980) was used to analyze the binding data. The use of this program enables models of receptors that best fit the given sets of data to be selected. The same program was also used to present the data in the form of Scatchard plots (Scatchard, 1949) and to compute values for receptor affinity $\left(K_{\mathrm{d}}\right)$ and density $\left(B_{\max }\right)$ that best fit the sets of binding data for each rat. Statistical comparisons of all the data were carried out with one way analysis of variance and the Student-Newman-Keuls test. Means among groups were considered significantly different when the $P$ value was less than 0.05 . Each individual experiment was performed in duplicate.

\section{RESULTS}

Frontoparietal cortical membranes from control and $A \beta$ (25-35)-treated rats bound ${ }^{125} \mathrm{I}-\mathrm{Tyr}^{11}$-SRIF in a timedependent manner, with an apparent equilibrium being observed between 50 and $180 \mathrm{~min}$ at $30{ }^{\circ} \mathrm{C}$. Hence, all subsequent experiments were conducted at $30{ }^{\circ} \mathrm{C}$ for 60 min. The injection of a single dose of $A \beta(25-35)$ did not modify the SRIF receptor density after 7 days of its administration. However, after 14 days of its administration, $A \beta$ (25-35) significantly decreased the SRIF receptor density and increased their affinity in the rat frontoparietal cortex (Fig. 1; Table 1). Frontoparietal cortical membranes from control and $A \beta$ (25-35)-treated rats showed a similar tracer degradation capacity and the values varied by no more than $10 \%$ in all experimental groups (data not shown).

The scrambled peptide $A \beta(35-25)$ was used to examine the effects of reversing the sequence of the active region of the peptide on the binding of ${ }^{125} \mathrm{I}-\mathrm{Tyr}^{11}$-SRIF to its receptors. A single administration of $A \beta(35-25)$ exerted no effect on the SRIF binding parameters at 14 days of its administration in all brain areas studied (Tables 1 and 3).

Because SRIF receptors have been shown to be negatively coupled to $\mathrm{AC}$, we examined basal and FK-stimulated AC activity as well as SRIF-mediated inhibition of the enzyme in membranes from the frontoparietal cortex. Basal and FK-stimulated AC activity were inhibited by SRIF in all the experimental groups studied. No significant differences in either basal or FK-stimulated AC activity or in SRIFmediated inhibition of both activities were detected in the frontoparietal cortical membranes from rats treated with a single dose of $A \beta$ (25-35) after 7 days of its administration. However, after 14 days of its single administration, the inhibitory effect of SRIF on basal and FK-stimulated AC activity was significantly lower in the $A \beta(25-35)$-treated rats as compared with controls (Table 2).

Since SRIF receptors are coupled to AC via Gi proteins, we next analyzed whether the levels of the inhibitory $\mathrm{G}$ protein subunits $\alpha \mathrm{i} 1$, $\alpha \mathrm{i} 2$ or $\alpha \mathrm{i} 3$ were affected by $\mathrm{A} \beta$ (25-35). To this aim, Western blot analyses were performed. A single dose of $A \beta(25-35)$ did not modify the 


\section{Frontoparietal cortex}

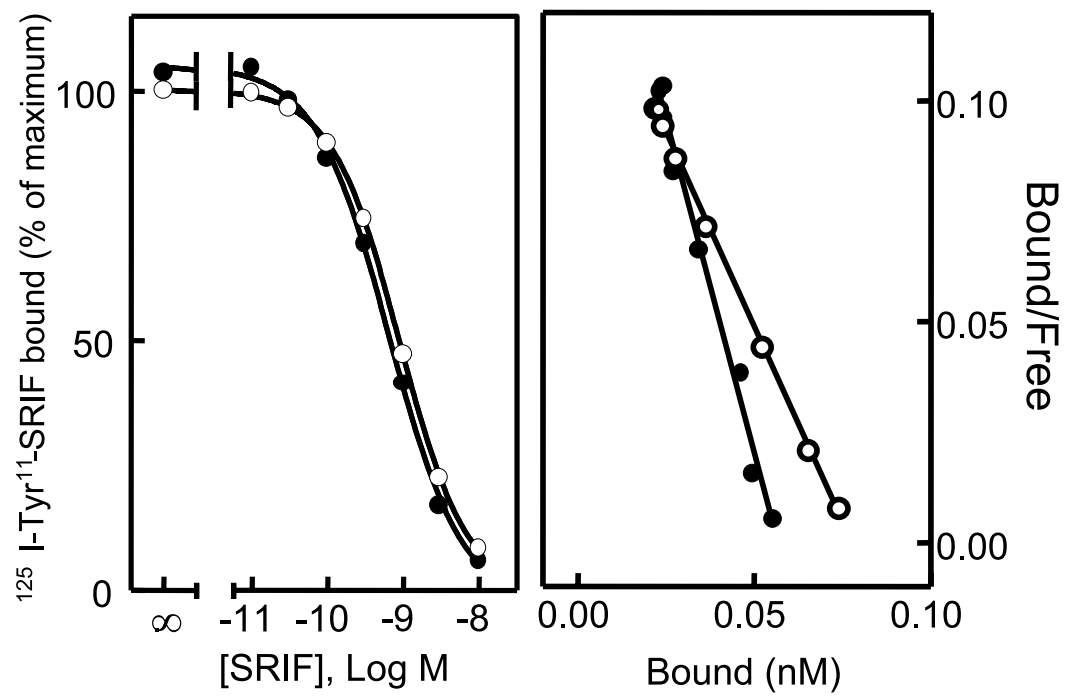

Fig. 1. Effect of a single dose $(10 \mu \mathrm{g})$ of $A \beta(25-35)$ after 14 days of its administration on SRIF binding to rat frontoparietal cortical membranes. Left panel: competitive inhibition of specific ${ }^{125}$-Tyr ${ }^{11}$-SRIF binding by unlabeled SRIF to frontoparietal cortical membranes. Membranes $(0.15$ mg protein/ml) were incubated for $60 \mathrm{~min}$ at $30^{\circ} \mathrm{C}$ in the presence of $250 \mathrm{pM}{ }^{125} \mathrm{I}-\mathrm{Tyr}{ }^{11}$-SRIF and increasing concentrations of native peptide. Points correspond to values from the control rats $(O)$ and rats treated with $A \beta(25-35)(\bullet)$. Each point represents the mean \pm S.E.M. of five rats. Each experiment was performed in duplicate. Right panel: Scatchard analysis of the binding data. The corresponding equilibrium parameters are included in Table 1.

levels of $\mathrm{Gi} \alpha 1$, Gi $\alpha 2$ or $\mathrm{Gi} \alpha 3$ in membranes from the frontoparietal cortex at 7 and 14 days of its administration (Fig. 2).

Since the neurodegenerative changes detected in $A D$ are caused by a continuous deposition of $A \beta$ at the cerebral level, we examined the effects of a continuous i.c.v. infusion of $A \beta$ (25-35) during 14 days. Continuous infusion of the peptide induced a decrease in the SRIF receptor density in the frontoparietal cortex to a similar extent as that observed at 14 days of the single administration of the peptide (data not shown). In order to further our knowledge on these effects, the same parameters were analyzed separately in the frontal cortex and parietal cortex of rats that received a continuous i.c.v. infusion of $A \beta(25-35)$ during 14 days. This treatment decreased the SRIF receptor density in the frontal cortex and parietal cortex (Figs. 3 and 4). This effect was accompanied by a decrease in SRIF-mediated inhibition of FK-stimulated $A C$ activity in the frontal cortex as well a decrease in basal $A C$ activity and FK-stimulated AC activity in the parietal cortex (Tables 3 and 4).

Continuous infusion of $A \beta(25-35)$ had no effect on the protein levels of $\mathrm{Gi} \alpha 1, \mathrm{Gi} \alpha 2$ or $\mathrm{Gi} \alpha 3$ in membranes from the frontal and parietal cortex (Fig. 2). However, it caused a decrease in SRIF-LI content in the frontal cortex (from $13.8 \pm 0.3$ to $8.4 \pm 0.1 \mathrm{ng}$ SRIF per $\mathrm{mg}$ of protein, ${ }^{* * *} P<0.001$ ) and parietal cortex (from 12.1 \pm 0.4 to $9.6 \pm 0.1 \mathrm{ng}$ SRIF per mg of protein, $\left.{ }^{* * *} P<0.001\right)$.

\section{DISCUSSION}

Recent studies carried out by Kubo et al. (2002) reinforce the hypothesis that soluble (D-ser-26)-A $\beta(1-40)$, possibly produced during aging, is released from plaques and converted by proteolysis to toxic (D-Ser-26)-A $\beta$ (25-35/40), which damages the neurons by enhancing exitotoxicity in

Table 1. Effect of a single dose of $A \beta(25-35)(10 \mu \mathrm{g})$ after 7 and 14 days of its administration or of $A \beta(35-25)(10 \mu \mathrm{g})$ at 14 days of its administration on the equilibrium parameters for SRIF binding in rat frontoparietal cortical membranes

\begin{tabular}{|c|c|c|c|c|}
\hline \multirow[t]{3}{*}{ Groups } & \multicolumn{4}{|c|}{ SRIF receptors } \\
\hline & \multicolumn{2}{|l|}{7 Days } & \multicolumn{2}{|l|}{14 Days } \\
\hline & $B_{\max }$ & $K_{\mathrm{d}}$ & $B_{\max }$ & $K_{\mathrm{d}}$ \\
\hline Control & $591 \pm 37$ & $0.67 \pm 0.06$ & $523 \pm 27$ & $0.59 \pm 0.03$ \\
\hline$A \beta(25-35)$ & $583 \pm 35$ & $0.62 \pm 0.06$ & $380 \pm 26^{* *}$ & $0.40 \pm 0.03^{* *}$ \\
\hline Control & & & $522 \pm 8$ & $0.58 \pm 0.05$ \\
\hline$A \beta(35-25)$ & & & $503 \pm 8$ & $0.53 \pm 0.04$ \\
\hline
\end{tabular}

Binding parameters were calculated from Scatchard plots by linear regression. Units for $K_{\mathrm{d}}$ are nM and units for $B_{\max }$ are fmol SRIF bound/mg protein. The results are the mean \pm S.E.M. of five separate experiments performed in duplicate. Statistical comparison vs. control: ${ }^{\star \star} P<0.01$. 
Table 2. Effect of a single dose of $A \beta(25-35)(10 \mu \mathrm{g})$ after 7 and 14 days of its administration on basal and FK-stimulated AC activity (pmol $\mathrm{cAMP} / \mathrm{min} / \mathrm{mg}$ protein) in frontoparietal cortical membranes from control $(n=10)$ and A $\beta(25-35)$-treated rats $(n=10)$

\begin{tabular}{|c|c|c|c|c|}
\hline & \multicolumn{2}{|l|}{7 Days } & \multicolumn{2}{|l|}{14 Days } \\
\hline & Control & $A \beta(25-35)$ & Control & $A \beta(25-35)$ \\
\hline Basal & $328 \pm 11$ & $298 \pm 14$ & $415 \pm 29$ & $372 \pm 19$ \\
\hline $10^{-4} \mathrm{M}$ SRIF & $228 \pm 20$ & $198 \pm 9$ & $269 \pm 18$ & $263 \pm 17$ \\
\hline $10^{-5} \mathrm{M} \mathrm{FK}$ & $1229 \pm 89$ & $1242 \pm 66$ & $1949 \pm 60$ & $1658 \pm 92$ \\
\hline $10^{-5} \mathrm{M} \mathrm{FK}+10^{-4} \mathrm{M}$ SRIF & $869 \pm 53$ & $856 \pm 39$ & $1298 \pm 68$ & $1358 \pm 91$ \\
\hline Fold FK stimulation over basal & $3.8 \pm 0.1$ & $4.2 \pm 0.3$ & $4.4 \pm 0.5$ & $4.4 \pm 0.3$ \\
\hline$\%$ SRIF inhibition of basal activity & $30 \pm 3$ & $33 \pm 3$ & $37 \pm 2$ & $29 \pm 1^{*}$ \\
\hline$\%$ SRIF inhibition of FK-stimulated activity & $31 \pm 4$ & $32 \pm 1$ & $33 \pm 4$ & $18 \pm 1^{* *}$ \\
\hline
\end{tabular}

Membrane preparations were incubated with or without SRIF $\left(10^{-4} \mathrm{M}\right)$ in the absence or presence of FK $\left(10^{-5} \mathrm{M}\right)$. Values represent the mean \pm S.E.M. of five separate experiments each performed in duplicate. Statistical comparison vs. control: ${ }^{*} P<0.05 ;{ }^{* *} P<0.01$.

AD. Thus, the short peptide $A \beta(25-35)$ has been proposed to be a functional domain of $A \beta$ responsible for its neurotoxic properties (Yankner et al., 1990; Pike et al., 1993). Damaged cells and neuronal loss in the neocortex as well as in the hippocampal subfields CA1 and CA3 and basal ganglia were observed after i.c.v. administration of $A \beta(25-35)$ to aged rats (Stepanichev et al., 2000). The dose of $A \beta(25-35)$ and the time period used in the present study were selected according to previous studies (Nitta et al., 1994). The $A \beta$-infused rat model is, at best, a partial model of AD. Maurice et al. (1996)) have demonstrated that i.c.v. administration of $A \beta$ (25-35) leads to $A \beta$ deposits widely disseminated throughout the frontoparietal cortex, which illustrates the relative facility with which $A \beta$ (25-35) diffuses throughout the brain after its administration into the lateral ventricle. The frontoparietal cortex was chosen for our study since moderate/severe AD pathology and reductions in SRIF receptor density have been detected in this brain area (Beal et al., 1985; Krantic et al., 1992).

The SRIF-LI levels in the control animals, as determined by radioimmunoassay, were similar to those previously reported by our group and other authors (Patel and Reichlin, 1978; Puebla and Arilla, 2003). Continuous infusion of $A \beta(25-35)$ led to a reduction in the SRIF-LI content in the frontoparietal cortex as well as in the frontal and parietal cortex when studied separately. The alteration in the SRIF levels demonstrated here parallels that detected in brains of patients with AD (Davies et al., 1980). Although $A \beta$ is thought by many researchers to be central to the pathogenesis of $A D$, it was unknown whether the peptide acts on somatostatinergic neurons. However, it is known that a SRIF deficiency is not due to a loss of SRIF-synthesizing interneurons (Dournaud et al., 1994) but rather to a reduction of the SRIF precursor molecule in senile dementia of the Alzheimer type (Pierotti et al., 1985). This could be due to a significant reduction in the expression of SRIF mRNA (Dournaud et al., 1994). Alterations in posttranslational processing could be due to alterations in proteolytic metabolism and peptidase activity, leading to changes in the metabolic half-life (Weber et al., 1992). More recently, Strittmatter et al. (1997) suggested the decrease of SRIF content is due to complex alterations of dysregulated synthesis and/or postranslational processing of SRIF. Recently, Tran et al. (2001) reported an impairment of cyclic AMP-response element-binding protein (CREB) signaling in neurons by $A \beta(25-35)$ at a concentration in which cell survival is not compromised. Since the cyclic AMP response element (CRE) of the SRIF promotor contains binding sites for CREB that are essential for CAMP-regulated transcription (Montminy and Bilezikjian, 1987; Andrisany and Dixon, 1990; Montminy et al., 1996), this mechanism might explain the decrease in SRIF-LI content seen in the present study.

The equilibrium parameters of the SRIF receptors in the frontoparietal cortex of control rats were similar to

Table 3. Effect of continuous infusion of $A \beta$ (25-35) (300 pmol/day) or $A \beta$ (35-25) during 14 days on the equilibrium parameters for SRIF binding in membranes from the rat frontal cortex and parietal cortex

\begin{tabular}{lllll}
\hline Groups & \multicolumn{2}{l}{ SRIF receptors } & & Parietal cortex \\
\cline { 2 - 4 } & \multicolumn{1}{l}{ Frontal cortex } & & $B_{\max }$ \\
\cline { 2 - 4 } & $B_{\max }$ & $K_{\mathrm{d}}$ & $539 \pm 61$ & $K_{\mathrm{d}}$ \\
\hline Control & $512 \pm 33$ & $0.55 \pm 0.1$ & $393 \pm 11^{*}$ & $0.60 \pm 0.01$ \\
A $(25-35)$ & $431 \pm 21^{*}$ & $0.43 \pm 0.06$ & $452 \pm 28$ & $0.50 \pm 0.01$ \\
Control & $482 \pm 25$ & $0.62 \pm 0.03$ & $508 \pm 20$ & $0.58 \pm 0.03$ \\
A $3(35-25)$ & $466 \pm 24$ & $0.64 \pm 0.04$ & 0.01 \\
\hline
\end{tabular}

Binding parameters were calculated from Scatchard plots by linear regression. Units for $K_{\mathrm{d}}$ are nM and units for $B_{\max }$ are fmol SRIF bound/mg protein. The results are the mean \pm S.E.M. of five separate experiments performed in duplicate. Statistical comparison vs. control: ${ }^{*} P<0.05$. 


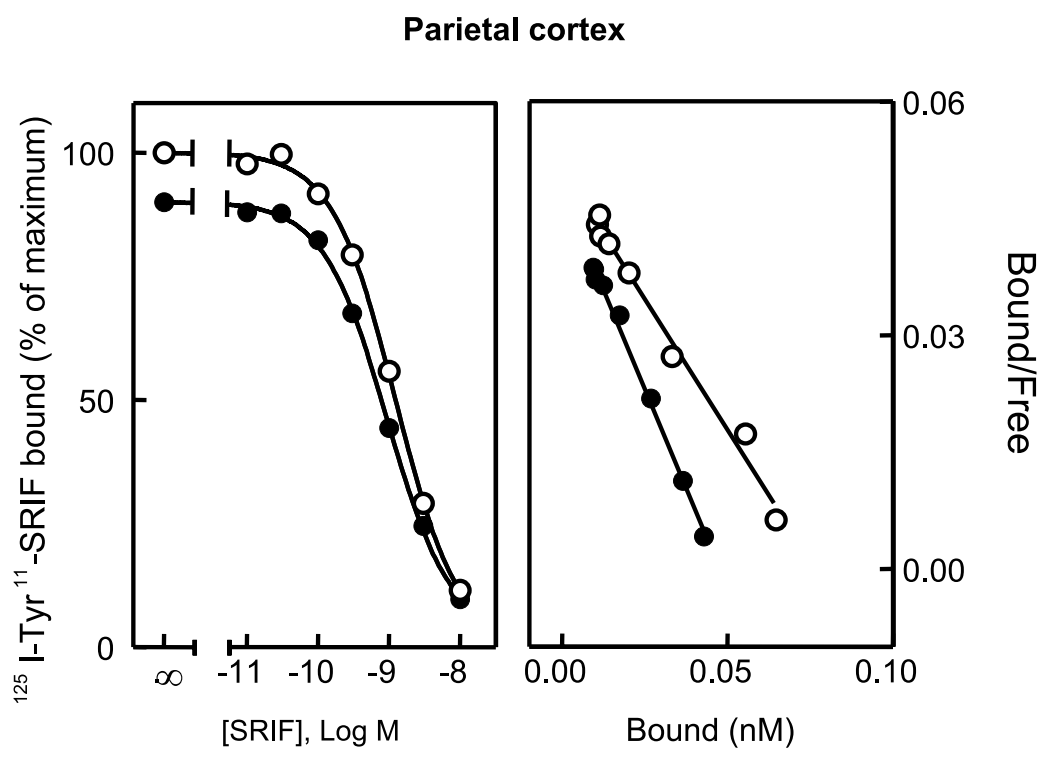

Fig. 2. Effect of continuous i.c.v infusion of $A \beta$ (25-35) (300 pmol/day) during 14 days on SRIF binding to membranes from the rat parietal cortex. Left panel: competitive inhibition of specific ${ }^{125}$ - -Tyr ${ }^{11}$-SRIF binding by unlabeled SRIF to membranes from the rat parietal cortex. Membranes $(0.15$ $\mathrm{mg}$ protein/ml) were incubated for $60 \mathrm{~min}$ at $30^{\circ} \mathrm{C}$ in the presence of $250 \mathrm{pM}{ }^{125} \mathrm{I}-\mathrm{Tyr}^{11}$-SRIF and increasing concentrations of native peptide. Points correspond to values from the control rats $(O)$ and rats treated with $A \beta(25-35)(\bullet)$. Each point represents the mean \pm S.E.M. of five rats. Each experiment was performed in duplicate. Right panel: Scatchard analysis of the binding data. The corresponding equilibrium parameters are included in Table 2 .

those previously reported by other authors (Srikant and Patel, 1981; Epelbaum et al., 1982). After 14 days of the single administration of $A \beta$ (25-35) and after continuous $A \beta$ (25-35) infusion, a decrease in the SRIF receptor density was observed in the rat frontoparietal cortex. These results are in agreement with those previously published in the postmortem frontoparietal cortex of $A D$ pa- tients (Krantic et al., 1992). The mechanisms underlying the $A \beta$ (25-35)-induced decrease in SRIF receptors is presently unknown. However, if the decrease in SRIF-LI observed in our study after $A \beta$ injection is due to an increased SRIF release, then this increased release could lead to a down-regulation of SRIF receptors. On the other hand, the CRE located in the promoter of the sst2 and sst3

\section{Frontal cortex}

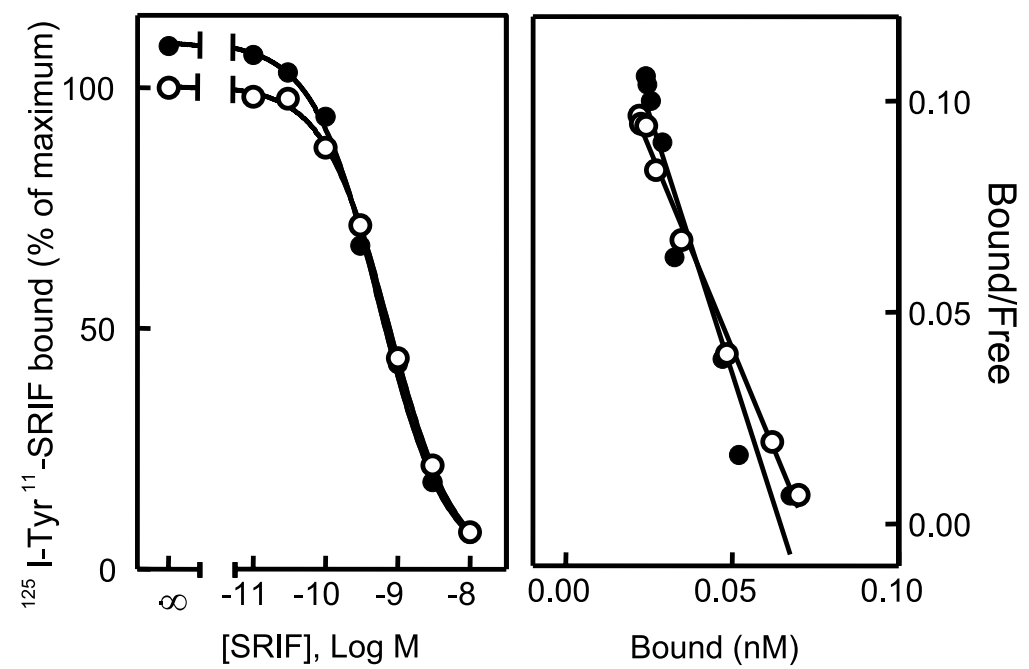

Fig. 3. - Effect of continuous i.c.v. infusion of $A \beta$ (25-35) (300 pmol/day) during 14 days on SRIF binding to membranes from the rat frontal cortex. Left panel: competitive inhibition of specific ${ }^{125} \mathrm{I}-\mathrm{Tyr}^{11}$-SRIF binding by unlabeled SRIF to membranes from the frontal cortex. Membranes $(0.15 \mathrm{mg}$ protein $/ \mathrm{ml}$ ) were incubated for $60 \mathrm{~min}$ at $30{ }^{\circ} \mathrm{C}$ in the presence of $250 \mathrm{pM}$ of ${ }^{125} \mathrm{I}-\mathrm{Tyr}{ }^{11}$-SRIF and increasing concentrations of native peptide. Points correspond to values from the control rats $(O)$ and rats treated with $A \beta(25-35)(0)$. Each point represents the mean $\pm S$.E.M. of five rats. Each experiment was performed in duplicate. Right panel: Scatchard analysis of the binding data. The corresponding equilibrium parameters are included in Table 2. 


\section{Frontoparietal cortex}

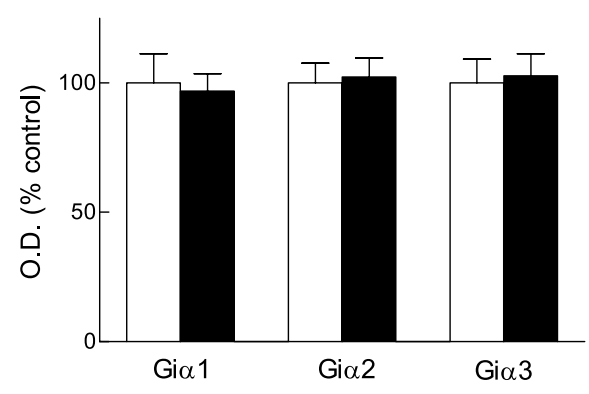

Frontal cortex

Parietal cortex
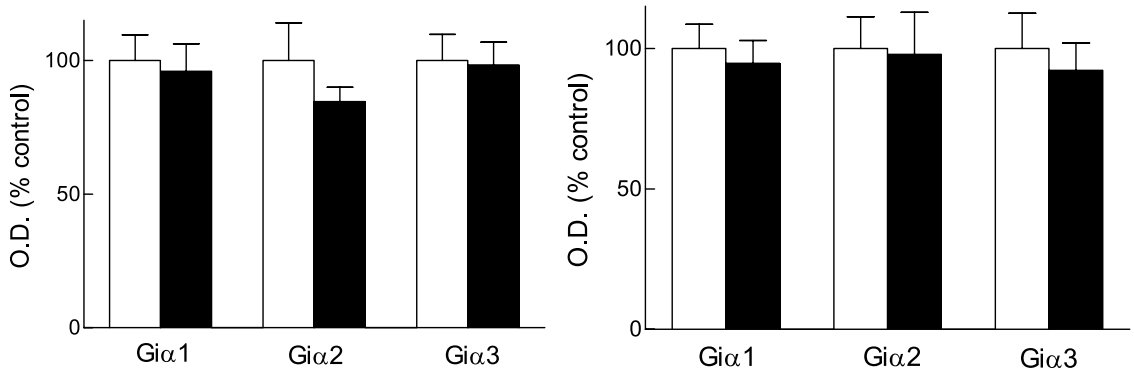

Fig. 4. Densitometric analysis of the autoradiographs derived from the immunoblots of the $\alpha \mathrm{i} 1$, $\alpha \mathrm{i} 2$ and $\alpha \mathrm{i} 3$ subunits of $\mathrm{G}$ proteins. Frontoparietal, frontal and parietal cortical membranes from control and $A \beta$ (25-35)-treated rats were resolved on SDS-PAGE as described in the Experimental Procedures section. Proteins were transferred to nitrocellulose membranes and the immunodetection was achieved using mouse anti-Gi 1 or anti-Gi $\alpha 2$ monoclonal antibodies or a rabbit anti-Gi $\alpha 3$ policlonal antibody. Each experiment is representative of five others. For details, see the Experimental Procedures section. Integrated optical densities for control autoradiographs were assigned an arbitrary value of 100 . Integrated optical densities for autoradiographs from frontoparietal, frontal and parietal cortical membranes following a single or continuous administration of $A \beta$ (25-35) are presented as a percent of the control value. Data represent the mean \pm S.E.M.

genes (Glos et al., 1998; Woltje et al., 1998), prominently expressed across the rat brain (Patel et al., 1993), is a prototype of a highly cAMP-responsive element regulated by the transcription factor CREB (Montminy et al., 1996). Since $A \beta(25-35)$ leads to an impairment of CREB signaling in neurons, it is possible, at least in part, that the mechanism underlying the $A \beta$ (25-35)-induced decrease in the number of SRIF receptors observed in the present study may involve transcriptional downregulation.

Finally, damaged cells and neuronal loss in the neocortex were observed after i.c.v. administration of $A \beta$ (2535 ) to rats (Stepanichev et al., 2000). Since SRIF recep- tors are present in different cell types in the rat brain, these findings may explain the decrease in the SRIF receptor density found in the present study. Moreover, due to the continuous infusion of the peptide into the brain, an increased concentration of $A \beta$ could alter the phosphoinositide metabolism of the membranes leading to a disorganization of biochemical structures (Prasad et al., 1998; Wells et al., 1995), and thus, to a decrease in the binding of SRIF to its receptors.

The scrambled peptide $A \beta(35-25)$ did not alter the SRIF binding parameters at any of the time-periods studied, which indicates that the $A \beta(25-35)$-induced decrease

Table 4. Effect of the continuous infusion of $A \beta$ (25-35) (300 pmol/day) during 14 days on basal and FK-stimulated AC activity (pmol cAMP/min/mg protein) in frontoparietal cortical membranes from control $(n=10)$ and $\mathrm{A} \beta(25-35)$-treated rats $(n=10)$

\begin{tabular}{|c|c|c|c|c|}
\hline & \multicolumn{2}{|l|}{ Frontal cortex } & \multicolumn{2}{|l|}{ Parietal cortex } \\
\hline & Control & $A \beta(25-35)$ & Control & $A \beta(25-35)$ \\
\hline Basal & $241.4 \pm 15.2$ & $248 \pm 42.2$ & $393.6 \pm 11.25$ & $319.15 \pm 18.7^{\star *}$ \\
\hline $10^{-4} \mathrm{M}$ SRIF & $172.3 \pm 9.7$ & $162.8 \pm 34.2$ & $254.8 \pm 13.3$ & $215.6 \pm 12.94$ \\
\hline $10^{-5} \mathrm{M} \mathrm{FK}$ & $678.1 \pm 50.1$ & $690.6 \pm 173$ & $1199.39 \pm 128.43$ & $1099.7 \pm 108.7$ \\
\hline $10^{-5} \mathrm{M} \mathrm{FK}+10^{-4} \mathrm{M}$ SRIF & $392.6 \pm 24$ & $473.4 \pm 145.7$ & $779.79 \pm 90.91$ & $773 \pm 82.86$ \\
\hline Fold FK stimulation over basal & $2.8 \pm 0.1$ & $3 \pm 0.3$ & $3.19 \pm 0.35$ & $3.61 \pm 0.19$ \\
\hline$\%$ SRIF inhibition of basal activity & $28.5 \pm 0.9$ & $31.1 \pm 0.8$ & $36.97 \pm 1.2$ & $31.68 \pm 1.28^{*}$ \\
\hline$\%$ SRIF inhibition of FK-stimulated activity & $41.9 \pm 1.1$ & $30 \pm 3.68^{*}$ & $35.64 \pm 1.4$ & $28.17 \pm 0.66^{* *}$ \\
\hline
\end{tabular}

Membrane preparations were incubated with or without SRIF $\left(10^{-4} \mathrm{M}\right)$ in the absence or presence of FK $\left(10^{-5} \mathrm{M}\right)$. Values represent the mean \pm S.E.M. of five separate experiments each performed in duplicate. Statistical comparison vs. control: ${ }^{*} P<0.05 ;{ }^{*} P<0.01$. 
in SRIF receptor density is a specific effect of the peptide. The reversal of the amino acid sequence in $A \beta$ (35-25) has been shown to alter the aggregation properties of the peptide from $\beta$-sheet to random coil formation, thereby reducing the neurotoxic effects on cultured cells (Buchet et al., 1996).

Basal and FK-stimulated AC activity was inhibited by SRIF in all the experimental groups, which is in agreement with the literature (Bergström et al., 1991; Garlind et al., 1992; Schettini et al., 1989). A high concentration of SRIF $\left(10^{-4} \mathrm{M}\right)$ was required to produce this inhibition although the same concentration was used by other researchers in their studies on SRIF-mediated inhibition of AC activity in the rat brain (Bergström et al., 1991; Garlind et al., 1992; Schettini et al., 1989). In a previous study from our group (Puebla and Arilla, 1995), the inhibitory effect of increasing SRIF concentrations on basal and FK $\left(10^{-5} \mathrm{M}\right)$-stimulated AC activity in control rats was analyzed. SRIF-mediated inhibition of $A C$ activity was only significant at the maximal concentration tested $\left(10^{-4} \mathrm{M}\right)$. Thus, this concentration was chosen for subsequent studies on $A C$ activity. It should also be noted that abundant studies on the SRIF effect on AC activity were performed in cell lines expressing higher levels of SRIF receptors than in animal tissues. In addition, it is tempting to speculate that because the frontoparietal cortex is very rich in SRIF-containing neurons, the amount of SRIF released may be sufficiently great as to justify the high SRIF concentration used to inhibit $A C$ activity.

$A \beta(25-35)$ administration led to a decrease in SRIFmediated inhibition of basal and FK-stimulated AC activity at 14 days of the single administration and after continuous i.c.v. infusion. However, no changes were detected in either basal or FK-stimulated AC activity, suggesting that the decreased sensitivity of AC to SRIF inhibition was not due to an alteration in the $A C$ catalytic subunit. In addition, Western blot analyses of $\mathrm{Gi} \alpha 1, \mathrm{Gi} \alpha 2$ and $\mathrm{Gi} \alpha 3$ proteins indicate that none of these proteins were modified by $A \beta$ (25-35). Taken together, the present results suggest that the decrease in SRIF-mediated inhibition of AC activity is most probably due to the decrease in the SRIF receptor density. Cowburn et al. (1992)) have shown a preservation of Gi-protein inhibited AC activity in the brains of patients with AD. O'Neill et al. (1994) also found that Gi-proteininhibited $A C$ activity was unaltered in the frontoparietal cortex of AD patients. Kato et al. (1991)) showed no difference in the relative abundance of $\mathrm{Gi} \alpha 2$ in the AD temporal cortex as compared with control values.

In relation to the specificity of $A \beta(25-35)$ on the SRIFergic system, other authors have shown that $A \beta$ (2535) also exerts effects on radioligand binding to excitatory amino acid receptors and voltage-dependent calcium channels, evidenced by a selective affinity for the glutamate and glycine recognition sites of the NMDA receptor (Cowburn et al., 1997). In addition, A $\beta$ (25-35) has been reported to alter the number and affinity of bradykinin, muscarinic and nicotinic receptors (Huang et al., 1998; Guan et al., 2003). All these findings, therefore, concur to indicate that the SRIFergic system is vulnerable to the toxicity of $A \beta$ (25-35) together with other neuronal systems. Thus, the $A \beta(25-35)$ infusions performed in our study might produce a general toxic effect that causes nonspecific effects on neurotransmitter systems.

The significance of our results is, at present, difficult to assess. However, potent amnesic properties were reported for the 11-amino acid fragment of $A \beta, A \beta(25-35)$ (Olariu et al., 2001; Yamaguchi and Kawashima, 2001). Several findings suggest a role for SRIF in cognitive processes such as learning and memory (Vécsei et al., 1984; Cacabelos et al., 1988). Recently, Dournaud and colleagues (1996) suggested that frontal and parietal somatostatinergic interneurons are likely to participate in learning behavior and in the regulation of spatial amnesic processes. Therefore, the reduction in SRIF receptors in both brain areas after infusion of $A \beta$ (25-35) might be involved in the impairment of cognitive function described after administration of $A \beta$ (25-35). In conclusion, the present results suggest that $A \beta$ might be involved in the alterations of the somatostatinergic system reported in AD. Nevertheless, it must be pointed out that there are some subtle differences between $A \beta$ (25-35) and the full-length peptide $A \beta$ (1-42). A $\beta$ (25-35) has often been studied as the potent component of the full-length peptide following the observation that it produces toxic effects similar to those caused by $A \beta 1-42$ such as neuronal death, protein oxidation, and lipid peroxidation in cell cultures (Varadarajan et al., 2001). However, the shorter peptide is more rapidly toxic than the full-length peptide and, in addition, often causes more oxidative damage. Furthermore, $A \beta 1-42$ has been shown to strongly bind $\mathrm{Cu}(\mathrm{II})$ ions and reduce them to $\mathrm{Cu}(\mathrm{I})$, whereas $\mathrm{A} \beta 25-35$ lacks the $\mathrm{Cu}(\mathrm{II})$ binding motif that was identified in A $\beta 1-42$ (Atwood et al., 1998). Therefore, great care must be taken when interpreting our results since there might be important differences in the mechanism of action of $A \beta 25-35$ and $A \beta 1-42$ in the pathogenesis of AD. Further studies will be necessary to explore these possible differences and compare the effects of the two peptides. Moreover, the possibility that the impairment of cognitive function associated with $A \beta$ (25-35) administration may be due, at least in part, to damage in some other neuronal system cannot be ruled out.

Acknowledgments-This work was supported by a grant (PM990129) from the Dirección General de Investigación del Ministerio de Ciencia y Tecnología of Spain.

\section{REFERENCES}

Aguilera G, Parker DS, Catt KJ (1982) Characterization of somatostatin receptor in the rat adrenal glomerulose zone. Endocrinology 111:1376-1384.

Andrisani OM, Dixon KE (1990) Somatostatin gene regulation. Annu Rev Physiol 52:793-806.

Armstrong RA, Myers D, Smith CV, Cairns N, Luthert PJ (1991) Alzheimer's disease: the relationship between the density of senile plaques, neurofibrillary tangles and A4 protein in human patients. Neurosci Lett 123:141-143.

Atwood CS, Moir RD, Huang X, Bacarra NME, Scarpa RC, Romano DM, Hartshorn MA, Tanzi RE, Bush Al (1998) Dramatic aggregation of Alzheimer abeta by $\mathrm{Cu}(\mathrm{II})$ is induced by conditions representing physiological acidosis. J Biol Chem 273:12817-12826. 
Beal MF, Mazurek MF, Tran VT, Chattha G, Bird ED, Martin JB (1985) Reduced numbers of somatostatin receptors in the cerebral cortex in Alzheimer's disease. Science 229:289-291.

Bell GI, Reisine T (1993) Molecular biology of somatostatin receptors. Trends Neurosci 16:34-38.

Bergström L, Garlind A, Nilsson L, Alafuzoff I, Fowler CJ, Windblad B, Cowburn RF (1991) Regional distribution of somatostatin binding and modulation of adenylyl cyclase activity in Alzheimer's disease brain. J Neurol Sci 105:225-233.

Buchet R, Tavitian E, Ristig D, Swoboda R, Stauss U, Gremlich HU, De La Fournier L, Staufienbiel M, Frey P, Lowe DA (1996) Conformations of synthetic beta peptides in solid state and in aqueous solution: relation to toxicity in PC12 cells. Biochim Biophys Acta 1315:40-46.

Cacabelos R, Niigawa $H$, Rodríguez-Arnao MD, Gomez-Pan A, Nishimura T (1988) Influence of somatostatin and growth hormone-releasing factor on behaviour. Horm Res 29:129-132.

Cagnin A, Brooks DJ, Kennedy AM, Gunn RN, Myers R, Turkheimer FE, Jones T, Banati RB (2001) In-vivo measurement of activated microglia in dementia. Lancet 358:461-467.

Cowburn RF, Fowler CJ, Garlind A, Alafozoff O, Nilsson L, Winblad B, Bergström $L$ (1991) Somatostatin receptors and the modulation of adenylyl cyclase activity in Alzheimer's disease. J Neurol Neurosurg Psychiatry 54:748-749.

Cowburn RF, Fowler CJ, O'Neill C (1996) Neurotransmitters, signal transduction and second-messengers in Alzheimer's disease. Acta Neurol Scand 165:25-32.

Cowburn RF, O'Neill C, Ravid R, Winblad B, Fowler CJ (1992) Preservation of Gi-protein inhibited adenylyl cyclase activity in the brains of patients with Alzheimer's disease. Neurosci Lett 141:16-20.

Cowburn RF, Wiehager B, Trief E, Li-Li M, Sundstrom E (1997) Effects of beta-amyloid-(25-35) peptides on radioligand binding to excitatory amino acid receptors and voltage-dependent calcium channels: evidence for a selective affinity for the glutamate and glycine recognition sites of the NMDA receptor. Neurochem Res 22:1437-1442.

Czernik AJ, Petrack V (1983) Somatostatin receptor binding in the rat cerebral cortex. Characterization using a nonreducible somatostatin analog. J Biol Chem 285:5525-5530.

Davies P, Katzman R, Terry RD (1980) Reduced somatostatin-like immunoreactivity in cerebral cortex from cases of Alzheimer's disease and Alzheimer senile dementia. Nature 288:279-280.

Dournaud P, Cervera-Pierrot P, Hirsch E, Javoy-Agid F, Kordon C, Agid Y, Epelbaum J (1994) Somatostatin mRNA-containing neurons in Alzheimer's disease: an in situ hybridization study in hippocampus, parahippocampal cortex and frontal cortex. Neuroscience 61:755-764.

Dournaud P, Jazat-Poindessous F, Slama A, Lamour Y, Epelbaum J (1996) Correlations between water maze performance and cortical somatostatin mRNA and high-affinity binding sites during ageing in rats. Eur J Pharmacol 8:476-485.

Epelbaum J, Tapia-Arancibia L, Cordón C, Enjalbert A (1982) Characterization, regional distribution and subcellular distribution of ${ }^{125}$ I-Tyr ${ }^{11}$-somatostatin binding sites in rat brain. J Neurochem 38:1515-1523.

Epelbaum J (1986) Somatostatin in the central nervous system: physiology and pathological modifications. Prog Neurobiol 27:63-100.

Feindt J, Becker I, Blomer U, Hugo HH, Mehdorn HM, Krisch B, Mentlein R (1995) Expression of somatostatin receptor subtypes in cultured astrocytes and gliomas. J Neurochem 65:1997-2005.

Feindt J, Schmidt A, Mentlein R (1998) Receptors and effects of the inhibitory neuropeptide somatostatin in microglial cells. Brain Res Mol Brain Res 60:228-233.

Garlind A, Fowler CJ, Alafuzoff I, Winbland B, Cowburn RF (1992) Neurotransmitter-mediated inhibition of post-mortem human brain adenylyl cyclase. J Neural Transm Gen Sect 87:113-124.
Garrett B, Finsen B, Wree A (1994) Parcellation of cortical areas by in situ hybridization for somatostatin mRNA in the adult rat: frontal, parietal, occipital and temporal regions. Anat Embryol (Berl) 190:389-398.

Glos M, Kreienkamp HJ, Haussmann H, Richter D (1998) Characterization of the $5^{\prime}$-flanking promoter region of the rat somatostatin receptor subtype 3 gene. FEBS Lett 440:33-37.

Glowinski J, Iversen LL (1966) Regional studies of catecholamines in the brain. I. The disposition of $\left[{ }^{3} \mathrm{H}\right]$ norepinephrine, $\left[{ }^{3} \mathrm{H}\right]$ dopamine and $\left.{ }^{3} \mathrm{H}\right] \mathrm{DOPA}$ in various regions of the brain. $\mathrm{J}$ Neurochem 13:655-669.

Gilman AG (1970) A protein binding assay for adenosine 3'5'-cyclic monophosphate. Proc Natl Acad Sci USA 67:305-312.

Giovannelli L, Casamenti F, Scali C, Bartolini L, Pepeu G (1995) Differential effects of amyloid peptides $\beta(1-40)$ and $\beta(23-35)$ injections in the rat nucleus basalis. Neuroscience 66:781-792.

Greenamyre JT, Penney JB, Young AB, D'Amato CJ, Hicks SP, Shoulson I (1985) Alterations in L-glutamate binding in Alzheimer's and Huntington disease. Science 227:1496-1498.

Greenwood FC, Hunter WM, Glover JS (1963) The preparation of $\left.\right|^{131} \mid$-labelled human growth hormone of high specific radioactivity. Biochem J 89:114-123.

Guan ZZ, Yu WF, Shan KR Nordberg A (2003) Loss of nicotinic receptors induced by beta-amyloid peptides in PC12 cells: possible mechanism involving lipid peroxidation. J Neurosci Res 71:397406.

Houslay MD, Metcalfe JC, Warren GB, Hesketh TR, Smith GA (1976) The glucagon receptor of rat liver plasma membrane can couple to adenylate cyclase without activating it. Biochim Biophys Acta 436:489-494

Huang HM, Ou H-C, Hsuch SJ (1998) Amyloid $\beta$ peptide enhanced bradykinin-mediated inositol $(1,4,5)$ triphosphate formation and cytosolic free calcium. Life Sci 69:195-203.

Kato K, Kurobe N, Suzuki F, Marishita R, Asano T, Imagaki T (1991) Concentrations of several proteins characteristic of nervous tissue in cerebral cortex of patients with Alzheimer's disease. J Mol Neurosci 3:95-99.

Katzman R, Saitoh T (1991) Advances in Alzheimer's disease. FASEB J 5:278-286.

Koshimura K, Kato T, Tohyama I, Nakamura S, Kameyama M (1986) Qualitative abnormalities of choline acetyltransferase in Alzheimer's type dementia. J Neurol Sci 76:143-150.

Krantic S, Robitaille J, Quirion R (1992) Deficits in the somatostatin $\mathrm{SS}_{1}$ receptor sub-type in frontal and temporal cortices in Alzheimer's disease. Brain Res 573:299-304.

Kubo T, Nishimura S, Kumagae Y, Kaneko I (2002) In vivo conversion of racemized $\beta$-amyloid ([D-Ser $\left.\left.{ }^{26}\right] A \beta 1-40\right)$ to truncated an toxic fragments ([D-Ser $\left.\left.{ }^{26}\right] \mathrm{A} \beta 25-35 / 40\right)$ and fragment presence in the brains of Alzheimer's patients. J Neurosci Res 70:474-483.

Laemmli UK (1970) Cleavage of structural proteins during the assembly of the head of bacteriophage T4. Nature 227:680-685.

Lowry OH, Rosenbrough NJ, Farr AL, Randall RJ (1951) Protein measurement with the Folin phenol reagent. J Biol Chem 193: 265-275.

Maurice T, Sockhart BP, Su TP, Privat A (1996) Reversion of betaamyloid peptide-induced amnesia by NMDA receptor-associated glycine site agonists. Brain Res 731:249-253.

Meda L, Cassatella MA, Szendrei GI, Otvos L Jr, Baron P, Villalba M, Ferrari D, Rossi F (1995) Activation of microglial cells by $\beta$-amyloid protein and interferon- $\gamma$. Nature 374:647-659.

Montminy MR, Bilezikjian LM (1987) Binding of a nuclear protein to the cyclic-AMP response element of the somatostatin gene. Nature 328:175-178.

Montminy M, Brindle P, Arias J, Ferreri K, Armstrong R (1996) Regulation of somatostatin gene transcription by cyclic adenosine monophosphate. Metabolism 45:4-7. 
Mumby SM, Kahn RA, Manning DR, Gilman AG (1986) Antisera of designed specificity for subunits of guanine nucleotide-binding regulatory proteins. Proc Natl Acad Sci USA 83:265-269.

Munson PJ, Rodbard D (1980) A versatile computerized approach for characterization of ligand binding system. Anal Biochem 107:220239.

Nag S, Yee BK, Tang F (1999) Reduction in somatostatin and substance $\mathrm{P}$ levels and choline acetyltransferase activity in the cortex and hippocampus of the rat after chronic intracerebroventricular infusion of beta-amyloid (1-40). Brain Res Bull 50:251-262.

Nitta A, Itoh A, Hasegawa T, Nabeshima T (1994) Beta-amyloid protein induced Alzheimer's disease animal model. Neurosci Lett 170:63-66.

Olariu A, Tran MH, Yamada K, Mizuno M, Hefco V, Nabeshima T (2001) Memory deficits and increased emotionality induced by $\beta$-amyloid (25-35) are correlated with the reduced acetylcholine release and altered phorbol dibutyrane binding in the hippocampus. J Neural Transm 108:1065-1079.

O'Neill C, Wiehager B, Fowler CJ, Ravid R, Winblad B, Cowburn RF (1994) Regionally selective alterations in $G$ protein subunit levels in the Alzheimer's disease brain. Brain Res 636:193-201.

Patel YC, Reichlin S (1978) Somatostatin in hypothalamus, extrahypothalamic brain, and peripheral tissues of the rat. Endocrinology 102:523-530.

Patel YC, Greenwood MT, Kent G, Panetta R, Srikant CB (1993) Multiple gene transcripts of the somatostatin receptor SSTR2: tissue selective distribution and cAMP regulation. Biochem Biophys Res Commun 192:288-294.

Pavia J, Alberch J, Alvarez I, Toledano A, Cevallos ML (2000) Repeated intracerebroventricular administration of beta-amyloid (25$35)$ to rats decreases muscarinic receptors in cerebral cortex. Neurosci Lett 278:69-72.

Pierotti A, Harmar A, Simpson J, Yates C (1985) High molecular weight forms of somatostatin are reduced in Alzheimer's disease and Down's syndrome. Neurosci Lett 63:141-146.

Pike CJ, Walencewicz-Wasserman AJ, Kosmoski J, Cribbs DH, Glabe CG, Cotman CW (1995) Structure-activity analyses of $\beta$-amyloid peptides: contributions of the $\beta 25-35$ region to aggregation and neurotoxicity. J Neurochem 64:253-265.

Pike CJ, Brudick D, Walencevicz AJ, Glab CG, Cotman CW (1993) Neurodegeneration induced by $\beta$-amyloid peptides in vitro: the role of peptide assembly state. J Neurosci 13:1676-1687.

Prasad MR, Lovell MA, Yatin M, Dhillon H, Markesbery WR (1998) Regional membrane phospholipid alterations in Alzheimer's disease. Neurochem Res 23:81-88.

Puebla L, Arilla E (1995) Exogenous histamine increases the somatostatin receptor/effector system in the rat frontoparietal cortex. Eur J Pharmacol 289:361-368.

Puebla L, Arilla-Ferreiro E (2003) Modulation of somatostatin receptors, somatostatin content and $\mathrm{Gi}$ proteins by substance $\mathrm{P}$ in the rat frontoparietal cortex and hippocampus. J Neurochem 84:145-56.

Reinikainen KJ, Soininen H, Riekkinen PJ (1990) Neurotransmitter changes in Alzheimer's disease: implications to diagnostics and therapy. J Neurosci Res 27:576-586.

Reubi JC, Perrin MH, Rivier JE, Vale W (1981) High affinity binding sites for a somatostatin-28 analog in rat brain. Life Sci 28 : 2191-2198.
Sakamoto C, Nagao M, Matozaki T, Nishizaki H, Konda Y, Baba S (1988) Somatostatin receptors on rat cerebrocortical membranes. Structural characterization of somatostatin-14 and somatostatin-28 receptors and comparison with pancreatic type receptors. J Biol Chem 263:14441-14445.

Scatchard G (1949) The attractions of proteins for small molecules and ions. Ann NY Acad Sci 51:660-671.

Schettini G, Florio T, Meucci O, Landolfi E, Grimaldi M, Ventra C, Marino A (1989) Somatostatin inhibition of adenylate cyclase activity in different brain areas. Brain Res 492:65-71.

Seamon KB, Daly JW (1986) Forskolin: its biological and chemical properties. Adv Cyclic Nucleotide Protein Phosphorylation Res 20:100-150.

Srikant CB, Patel YC (1981) Somatostatin receptors: identification and characterization in rat brain membranes. Proc Natl Acad Sci 78:3930-3934.

Stepanichev MYu, Onufriev MV, Mitrokina OS, Moiseeva YuV, Lazareva NA, Viktorov IV, Gulyaeva NV (2000) Neurochemichal, behavioural and neuropharmacological effects of central administration of betaamyloid peptide (25-35) in rat. Neurochem (Nejrokhimija Rus) 17:291-306.

Strittmatter M, Cramer H, Reuner C, Strubel D, Hamann G, Schimrigk K (1997) Molecular forms of somatostatin-like immunoreactivity in the cerebrospinal fluid of the cerebrospinal fluid of patients with senile dementia of the Alzheimer type. Biol Psychiatry 41:11242230.

Tran MH, Yamada K, Olarin A, Mizuno M, Ren XH, Nabeshima T (2001) Amyloid $\beta$-peptide induces nitric oxide production in the rat hippocampus: association with cholinergic dysfunction and amelioration by inducible nitric oxide synthase inhibitors. FASEB $\mathrm{J}$ 15:1407-1409.

Varadarajan S, Kanski J, Aksenova M, Lauderback C, Butterfield DA (2001) Different mechanisms of oxidative stress and neurotoxicity for Alzheimer's $A \beta(1-42)$ and $A \beta(25-35)$. J Am Chem Soc 123:5625-5631.

Vécsei L, Bollok I, Telegdy G (1984) Phenoxybenzamine antagonizes somatostatin-induced anti-amnesia in rats. Eur J Pharmacol 99: 325-328.

Weber SJ, Louis RB, Trombley L, Bisette G, Davies P, Davies TP (1992) Metabolic half-life of somatostatin and peptidase activities are altered in Alzheimer's disease. J Gerontol 47:B18-B25.

Wells K, Farookui AA, Liss L, Horrocks LA (1995) Neural membrane phospholipids in Alzheimer disease. Neurochem Res 20:1329 1333.

Woltje M, Kraus J, Hollt V (1998) Identification of a functional 3', $5^{\prime}$-cyclic adenosine monophosphate response element within the second promoter of the mouse somatostatin receptor type 2 gene. FEBS Lett 440:107-110.

Yamaguchi Y, Kawashima S (2001) Effects of amyloid- $\beta$-(25-35) on passive avoidance, radial-arm maze learning and choline acetyltransferase activity in the rat. Eur J Pharmacol 412:265-272.

Yankner BA, Duffy LK, Kirshnet DA (1990) Neurotrophic and neurotoxic effects of amyloid $\beta$ protein: reversal by tachykinin neuropeptides. Science 250:279-282. 